\title{
ONLINE K-12 EDUCATION: OPPORTUNITIES FOR COLLABORATION WITH HIGHER-EDUCATION
}

\author{
Melody M. Thompson \\ Penn State University
}

\begin{abstract}
It is common practice for researchers and developers of innovative programs, as well as for the foundations and agencies that provide support for such research and programming, to target their efforts on specific segments of the educational system: $\mathrm{K}-12$ or higher education, for example. However, the growing acceptance of the idea that society as a whole will benefit from a move toward a seamless " $\mathrm{K}-$ 16 " system suggests that such compartmentalization is no longer appropriate, whether for traditional or online education. This paper addresses issues of how and in what ways those in K-12 and higher education can fruitfully collaborate in three growing areas of online practice: dual (or concurrent) enrollment programs for high-school students, alternative routes for teacher certification for mid-career changers, and professional development for practicing teachers.
\end{abstract}

\section{KEYWORDS}

K-16, Collaboration, Dual Enrollment, Teacher Certification, Professional Development

\section{BACKGROUND}

Concerns about the inadequacies of the current educational pipeline to prepare and motivate students for the postsecondary educational attainment necessary for social and economic success have prompted numerous educational reforms. However, despite the pressing social need for greater participation in postsecondary education and the reforms intended to encourage it, only $67 \%$ of the students who enter 9th grade graduate from high school within four years, only $38 \%$ enter college, only $26 \%$ are still enrolled in college after their sophomore year, and only $18 \%$ graduate with either an Associate's degree or Bachelor's degree within three or six years, respectively. The percentages are significantly lower for lowincome and minority students [1]. As a result, the United States, once first in the proportion of its population aged 24-35 to obtain postsecondary degrees, is now in fifth place worldwide [2].

Increasingly, attention is focusing on education as an integrated $\mathrm{K}-16$ continuum, rather than as separate systems, and on how to make the continuum a more effective overall system. A number of conferences and task forces have focused on the need for closer collaboration between $\mathrm{K}-12$ and higher education as the only way to ensure the quality and equity of educational opportunities for students at all levels [3]. Collaboration has also been tied to the goal of increasing post-secondary enrollments. A recent national task force report [2, p. 9] proposed that "if the end goal is having more young people attain postsecondary credentials more quickly - with less waste of time and resources-attention should focus not only on better preparation at each level but also on the connections between the $K-12$ and postsecondary education systems" (emphasis in the original). Specific areas of focus recommended for K-12-highereducation collaborations include:

- Increasing high-school students’ participation in AP courses and dual-enrollment programs [2]; 
- Expanding the pool of $\mathrm{K}-12$ teachers and improving professional development of practicing teachers as a means for ensuring high-quality teaching for all students [4]; and

- Developing consistent and complementary standards of program quality and student achievement [3].

\section{EXTENT OF K-12 ONLINE EDUCATION}

Online education in $\mathrm{K}-12$ schools is a relatively new, but rapidly growing, educational phenomenon. A recent publication of the National Center for Education Statistics reported 328,000 enrollments in distance education courses (all technologies) among public school students during the 2002-2003 school year [5]. Although the prediction of the Education Commission of the States that more than one in five K-12 students will be receiving a substantial portion of their instruction online by 2005 [6] has proven to be overly optimistic, the fact that $72 \%$ of school districts currently offering distance courses reported that they expect to expand their e-learning programming in the future provides an indication of things to come.

The increasing official acceptance of online education for school children is reflected in the U.S. Department of Education's recognition of the potential of virtual schools to help states meet the educational requirements of the No Child Left Behind legislation and the resulting designation of online education as an acceptable way for school districts to create additional capacity for high-quality education [6].

\section{BUILDING ON CURRENT CONNECTIONS BETWEEN K-12 AND HIGHER EDUCATION}

There are several readily apparent connections between $\mathrm{K}-12$ education and higher education that suggest the potential for beneficial partnerships related to online activities. Areas of previously developed connections that have already been, or could be, extended into the online environment include: collegelevel courses for high-school students; training of career-transition professionals to become K-12 teachers; and professional development courses for practicing teachers.

\section{A. College-Level Courses for High-School Students}

A recent survey of college admissions officers reported that the most important factor in college admissions is student success in challenging courses, and the U.S. Department of Education has noted that a rigorous, high-quality high-school curriculum, such as that which includes access to AP courses, is the strongest predictor of bachelor's degree completion [7]. Also important is a clear understanding of expectations for college-level work.

Dual enrollment programs, in which high-school students take college-level courses for credit, can contribute to a successful transition from high school to post-secondary study by increasing the academic rigor of the high-school experience and by establishing an understanding of expectations for college-level work [8]. Currently, 40 states have dual enrollment policies, with 18 states mandating that dual enrollment opportunities be provided. However, "eligibility and tuition requirements, funding streams and program features vary widely from state to state” [9]. Often, the conflicting priorities of states, highereducation institutions, and high schools become barriers to the goal of broadening accessibility of these programs beyond the academically talented to other students who would benefit from a more challenging curriculum and/or expanded curricular offerings. 
Although to date few rigorous studies of dual-enrollment programs have been conducted, preliminary research suggests several specific benefits. In several studies, students reported that the programs were useful and motivated them to enroll in college; in other studies, dual-enrollment participants were reported as graduating from both high-school and college at higher rates than those who did not take dualenrollment courses [10]. A Florida study reported that high-school students who participate in dualenrollment programs enroll in post-secondary institutions at rates significantly higher than students who do not participate in such programs, with the rates being even higher for Hispanic and African-American students than for white students (Florida Department of Education 2004, cited in [2]).

However, as the Renewing Our Schools report points out, merely creating new alternatives does not ensure the teaching and leadership capacity necessary to implement such programs. Increased access to AP courses and dual-enrollment options will depend on better collaboration between $\mathrm{K}-12$ and higher education, collaboration that includes online approaches:

Distance learning and other technology-based strategies lend themselves well to accelerated work on college-level classes. The extensive technology-based systems of many institutions of higher education would allow them to deliver course content, provide feedback to students, and give students remote access to top-quality professors and courses. [2]

The most recent report from the National Center for Educational Statistics [5] estimates that 45,300 students were enrolled in Advanced Placement or college-level courses offered through distance education in the 2002-2003 school year. This figure represents $14 \%$ of all distance education enrollments and $18 \%$ of the school districts offering AP courses. The proportion of enrollments in this category varies by geographic location and district size, with rural districts and small districts having a higher proportion of students enrolled in these courses compared to urban and larger districts. The current proportionally low level of online activity suggests the potential for considerable impact from collaborations between higher education and K-12 education in this area of practice.

\section{B. Professional Development for Practicing Teachers}

According to the National Staff Development Council, there is a direct connection between high-quality teacher professional development and students' academic performance [11]. Ongoing, high-quality professional development has been tied specifically to the goal of assuring equity for all students [4].

Research and experts on teacher professional development agree that high-quality professional development activities have a number of common characteristics:

- Ongoing as opposed to one-time

- Reflect realities of teachers' schedules

- Tied directly to teaching and learning objectives

- Provide hands on experience

- Provide opportunities for immediate application and reflection

- Provide opportunities for collegial sharing and mentoring [11, 12, 13].

Many traditional forms of professional development lack these essential elements of quality. For example, although research shows that sustained activities are much more effective in bringing about positive effects in the classroom, the traditional short "one-off" workshop continues to be the form of activity in which most teachers participate. Similarly, although standards for high-quality development emphasize the importance of hands-on experience, many traditional professional development activities fail to 
incorporate such experiences. It is no wonder that only $20 \%$ of teachers report that their professional development activities have had a significant positive impact on their teaching [14].

Recognizing the benefits to teachers, students, and school districts, a number of educational associations and policy groups-including the National Middle School Association, the National Association of State Boards of Education, the CEO Forum on Education and Technology, and the National Staff Development Council-are promoting online professional development for teachers. These groups all note that online learning can provide opportunities that reflect the characteristics identified as necessary for high-quality professional development.

For example, the National Association of State Boards of Education has concluded that "e-learning will improve American education in valuable ways and should be universally implemented as soon as possible” [4, p. 4]. This group has also drawn an explicit connection between adoption of e-learning for schoolchildren and use of online education for teacher professional development:

The fact that 98 percent of all U.S. schools are now connected to the Internet offers unprecedented opportunities for educators as well as their students to take advantage of "any time, any place, any path, any pace" e-learning to enhance their pedagogical and administrative skills in an ongoing manner. The Internet can potentially deliver to every educator in every school a wide variety of formal and informal courses available on demand, from brief skills-boosting courses to labor-intensive master's degrees. Online learning allows teachers and administrators to experience the same instructional practices they are expected to use with their students, such as project-based learning, assembling electronic portfolios, and searching out and critically evaluation information on the Internet [4, p. 30].

In referring specifically to professional development aimed at helping teachers integrate technology into the classroom, a CEO Forum report notes that

Few techniques are more effective than learning by doing.... Teachers should use technologies such as distance learning, online networking, and web-and computer-based classes to access professional development resources [15, p. 20].

This observation is particularly true of a sub-category of teacher professional development: that needed by those K-12 teachers who teach online through virtual schools, consortium-like arrangements among public schools, or other structures. The particular skills and strategies needed by these teachers can best be gained and implemented via the experience of their own learning via the medium or media through which they themselves teach.

Several recent research reports also support the value of online teacher professional development. A study of an online professional development program for rural teachers and administrators found that the program had a positive influence on teacher collaboration and community building, teacher instructional improvements, and administrator leadership practices [16]. Researchers investigating the effectiveness and cost of an online professional development program for reading teachers in Tennessee reported high levels of teacher satisfaction with the program, substantial improvements in teacher knowledge, preliminary evidence of improvement in student outcomes, and increased cost-effectiveness when compared to the traditional face-to-face format [17].

Unfortunately, neither the clear potential of online delivery to extend high-quality professional development to teachers nor the endorsement by national and federal policy groups has been sufficient to 
ensure widespread participation by teachers or financial reimbursement for such programs by school districts $[18,19]$. As a result, collaboration between $\mathrm{K}-12$ and higher education around the delivery of online teacher development programs remains undeveloped to the detriment of both groups: higher education institutions that could benefit from the enrollment of mature, committed students and K-12 teachers, many of whom could benefit from effective, convenient, and cost-effective professional development opportunities.

Increasing collaboration in this area will depend at least in part on providing $\mathrm{K}-12$ decision makers and teachers themselves with information on the benefits of online education in meeting school districts' and teachers' professional development goals, as well as on helping them identify barriers to and strategies for more widespread adoption. Concurrently, those in higher education must be given evidence of the benefits of-and convinced of their responsibilities in-developing collaborative relationships focused on these goals.

\section{Online Training of Career-Transition Professionals}

The U.S. Department of Education notes that traditional teacher preparation programs will not be able to supply the two million new teachers needed to meet the nation's need for "highly qualified" teachers, as defined by the No Child Left Behind legislation. Teacher retirements, tightening standards, high attrition rates among beginning teachers, and a growing student population are stressing an already inadequate teacher-preparation system. Alternative routes to teacher certification are increasingly being adopted to meet the need for more and more qualified teachers. As of 2004, 43 states had implemented some type of alternative process for certifying teachers; currently, 20\% or more of new teachers enter the profession through alternative routes, such as the Troops to Teachers program [20]. In some states, the proportion is over $50 \%$ [21].

Although traditionally delivered alternative programs for certification have helped to some extent in easing teacher shortages, they cannot train nearly enough prospective teachers to meet the demand [22, 21]. Additionally, for the mid-career professional attempting to juggle multiple roles, the fixed-site, fixedtime nature of such programs can be an insurmountable obstacle.

Alternative routes to certification offered on line provide benefits to all stakeholders, and their effectiveness has been demonstrated through participants' performance on state-mandated competency tests [23]. However, as with online in-service professional development, lack of knowledge about, or acceptance of, the online options have limited the potential impact of these programs. K-12 opinion leaders and decision makers must be educated about the potential of high-quality online educational programs to meet the urgent social need for more teachers. Strategic collaboration between the higher education institutions and K-12 stakeholders is necessary to foster the growth and acceptance of this method of alternative program delivery.

\section{CONCLUSION}

The pressing need to improve the effectiveness of the overall national system of education means that higher education and K-12 education can no longer be viewed as separate systems. Online learning offers a particularly relevant focus for collaboration in the move toward a seamless $\mathrm{K}-16$ system. Three areas are particularly amenable to online options: AP and dual-enrollment courses for high-school students, teacher professional development, and training of career-transition professionals to become teachers. Building and sustaining $\mathrm{K}$-12-higher-education collaborations in these areas can strengthen the educational pipeline through better-prepared students and highly qualified teachers. 


\section{ABOUT THE AUTHOR}

Melody M. Thompson, D.Ed., is Assistant Professor of Education in Penn State's College of Education. In that role, she teaches and advises graduate students in the Adult Education Program, with much of her teaching being done online through the Penn State World Campus. She is also the Faculty Satisfaction editor for the Sloan Consortium's Effective Practices database. Her primary research interests are faculty satisfaction and the institutional policy environment for online learning, as well as diversity issues in adult education. Dr. Thompson's past positions include Director of Planning and Research for the World Campus and Director of the American Center for the Study of Distance Education (ACSDE). Dr. Thompson is the author of numerous articles and book chapters, as well as co-author of the McGraw-Hill Handbook of Distance Learning.

\section{ACKNOWLEDGEMENTS}

I would like to thank Ramo Lord, graduate assistant in the Penn State Adult Education Program, for assistance in developing this article.

\section{REFERENCES}

1. Ewell, P., D. Jones and P. Kelly. Conceptualizing and researching the educational pipeline. A report of the National Center for Higher Education Management Systems (NCHEMS), 2003. http://www.higheredinfo.org/analyses/.

2. Pennington, H. Fast track to college: Increasing postsecondary success for all students. Report prepared for Renewing Our Schools, Securing Our Future. A National Task Force on Public Education, 2004. http://www.americanprogress.org/site/pp.asp?c=biJRJ8OVF\&b=263325.

3. Gathering Momentum. The Hechinger Institute on Education and the Media, The Institute for Educational Leadership, and The National Center for Public Policy and Higher Education, 2002. http://www.highereducation.org/catreports/K16.shtml.

4. National Association of School Boards of Education. Any time, any place, any path, any pace: Taking the lead on e-Learning Policy. Alexandria, VA: NASBE, 2001. http://www.nasbe.org/Organization_Information/e-learning.pdf.

5. Setzer, J.C. and L. Lewis. Distance education courses for public elementary and secondary school students: 2002-2003. (NCES 2-5-010) U.S. Department of Education. Washington, DC: National Center for Education Statistics, 2005. http://nces.ed.gov/pubsearch/pubsinfo.asp?pubid=2005010.

6. Hassel, B. and M. Terrell. How can virtual schools be a vibrant part of meeting the choice provisions of the No Child Left Behind Act? Virtual School Report, Summer 2004. http://www.connectionsacademy.com/virtualreport.asp.

7. Advanced Placement Report to the Nation. New York, NY: The Advanced Placement program of the CollegeBoard, 2005. http://apcentral.collegeboard.com/article/0,3045,149-0-0-41919,00.html.

8. Karp, M., T. Bailey, K. Hughes and B. Fermin. Update to State Dual Enrollment Policies: Addressing Access and Quality. Report prepared for the U.S. Department of Education, Office of Vocational and Adult Education, 2005 http://www.ed.gov/about/offices/list/ovae/pi/cclo/cbtrans /statedualenrollment.pdf.

9. Education Commission of the States. New programs, policies aim to improve students' preparation for and access to postsecondary education. [Electronic version]. The Progress of Education Reform 2005 6(3): 1, 2005.

10. Bailey, T., K. Hughes and M. Karp. Dual enrollment programs: Easing transitions from high school to college. CCRC Brief. New York, NY: Community College Research Center (ERIC Document Reproduction Service No. ED 475805), 2003. 
11. National Staff Development Council. Standards for Staff Development. Oxford, OH: National Staff Development Council, 2001.

12. Rodriguez, G. Critical issue: Providing professional development for effective technology use. A report of the North Central Regional Educational Laboratory, 2000. http://www.ncrel.org/sdrs /areas/issues/methods/technlgy/te1000.htm.

13. Griffin, D. Standards for online professional development. Atlanta: Southern Regional Education Board, 2004. http://www.sreb.org/programs/EdTech/pubs/PDF/StandardsOnlineProfDev.asp

14. U.S. Department of Education, National Center for Education Statistics. The Condition of Education 2002. NCES 2002-05, Washington, DC: U.S. Government Printing Office, 2002. http://nces.ed.gov/programs/coe/.

15. Professional Development: A Link to Better Learning. Year 2 Report of the CEO Forum on Education and Technology, 1999. http://www.ceoforum.org/reports.html.

16. Lauer, P., K. Stoutemyer and R. Van Buhler. The McREL Rural Technology Initiative: Research and evaluation study. Aurora, CO: McRel [Mid-continent Research for Education and Learning], (ERIC Document Reproduction Service No. ED486628), 2005.

17. Cavalluzzo, L., D. Lopez, J. Ross, M. Larson and M. Martinez. A study of the effectiveness and cost of AEL's online professional development program in reading in Tennessee. Charleston, WV: Advantia [Appalachia Educational Laboratory at Edvantia], (ERIC Document Reproduction Service No. ED 489124), 2005.

18. Richardson, J. A matter of online degrees. The School Administrator Web Edition, October 2001. http://www.aasa.org/publications/sa/2001_10/richardson_degrees.htm.

19. Thomas, W. Online professional development. Why SREB states should use it. Atlanta: Southern Regional Education Board, 2004. http://www.sreb.org/programs/EdTech/pubs/PDF/Online ProfessionalDevelopment.asp.

20. U.S. Department of Education, Office of Innovation and Improvement. Innovations in Education: Alternative Routes to Teacher Certification, Washington, D.C., 2004. http://www.ed.gov/admins /tchrqual/recruit/altroutes/index.html.

21. Simmons, S. C. and D. J. Mebane. NC TEACH and NC TEACH OnLine: Viable alternative routes to teaching in North Carolina. Action in Teacher Education 27(1): 45-52, 2005. Retrieved March 10, 2006, from ERIC database.

22. Dennis, G. and S. Emberton. Going the distance in teacher certification: An exploration of online delivery, 2003. http://people.uis.edu/rschr1/onlinelearning/archive/2004_02_15_archive.html.

23. Mann, G., E. Henderson and T. Guffy. Meeting the unmet challenge: Alternative certification programs through the use of technology. Texas: 2002. Retrieved March 10, 2006, from ERIC database. 